\title{
La más reciente superación del marxismo
}

\section{György Lukács'}

\begin{abstract}
Nota del traductor
El documento que a continuación se presenta por primera vez en español constituye una reseña de Lukács a Prusianismo y socialismo, obra que Oswald Spengler publicó en 1919. La reseña apareció originalmente en 1920 en Kommunismus, cuya redacción dirigía en parte el propio Lukács. En 1970, se editaría en una colección de ensayos pirata titulada Organisation und Partei y en 1975, en la antología editada por Jorg Kämmler y Frank Benseler Taktik und Ethik, que reúne los ensayos políticos de Lukács correspondientes al período revolucionario de 1919 y los primeros tiempos del exilio vienés.
\end{abstract}

En la reseña, Lukács presenta, con tono burlón, las dificultades de Spengler para comprender el marxismo y afirma que lo único interesante del libro es su naturaleza "de síntoma" de los tiempos en los que fue escrito. Años después, con la experiencia del nazismo a sus espaldas, en El asalto a la razón Lukács seguirá resaltando que la obra (sobre todo La decadencia de Occidente) de Spengler es "un documento en verdad representativo de esta etapa", pero añadirá que es "el preludio real y directo de la filosofía del fascismo" (1967:373). En efecto: considera allí que este "librito" es consecuencia necesaria de la corriente irracionalista moderna que se remonta a tiempos de Schelling; es otra "discrepancia entre la imagen mental y el original objetivo" (1967: 79) del problema del socialismo. Teniendo en cuenta que el irracionalismo, en palabras de Lukács, "mistifica el problema, convertido así, artificiosamente, en insoluble, haciendo de él una solución “superracional”' (1967: 77), el texto de Spengler se inscribe a la perfección en esta corriente: "La guerra mundial, en el atardecer de la cultura occidental, constituye el formidable choque entre ambas ideas germánicas, que como todas las ideas verdaderas, no se expresan, sino que se viven" (2014:12). ${ }^{2}$

1 György Lukács, "Die neueste Überwindung des Marxismus". En Kommunismus, año 1, vol. 5, 22 de febrero de 1920, pp. 155-156. Trad. del alemán por Fermín Gdansky Orgambide (Universidad de Buenos Aires).

2 La traducción difundida por la editorial Sieghels no hace justicia al verbo leben (vivir) y la carga conceptual que el término tiene en las filosofías alemanas reaccionarias de comienzos de siglo. Por lo tanto, cambiamos "experimentan" por "viven". 
El ensayo de Spengler es un texto de posguerra, formulado en el comienzo de la República de Weimar, que se pregunta por el "golpe de Estado del elemento inglesado" (2014: 13) en Alemania -luego de que su autor, así como una enorme parte de la intelectualidad alemana, hubiera apoyado y promovido la campaña bélica-. Frente a la cuestión por la esencia del socialismo, bullada y sin respuesta concreta, Spengler se propone explicar el "verdadero" significado del término dejando atrás cualquier vestigio de Marx. De ahí el título de la reseña de Lukács, quien contundemente se refiere a Spengler como un "filósofo de moda".

Fermín Gdansky Orgambide

Universidad de Buenos Aires 
La más reciente superación del marxismo...

\section{Q Bibliografía}

"Lukács, G. (1967). El asalto a la razón. La trayectoria del irracionalismo desde Schelling hasta Hitler. Trad. de W. Roces. México: FCE.

"Spengler, O. (2014). Prusianismo y socialismo. Trad. de O. Dangschadt. Buenos Aires: Sieghels, 2014. 
Rara vez pasa un año sin que Marx sea definitivamente "superado" por algún profesor asociado ${ }^{3}$ ambicioso o un filósofo de moda. La lucha a muerte que la sociedad burguesa ha de librar se da también en el terreno de la ideología. Estas superaciones muestran, para el observador atento, un semblante curiosamente constante. El tenor de la demostración cambia, los argumentos epistemológicos o metafísicos también parecen ser siempre nuevos; pero su naturaleza básica, el punto de partida y el objetivo final siguen siendo los mismos. Provienen de la constitución pequeñoburguesa y parasitaria de la situación de clase de los intelectuales. Como genuinos pequeños burgueses, los eruditos son incapaces de ver correctamente el hecho de la lucha de clases, por no hablar de evaluarlo correctamente. Exigen, como dice Marx, instituciones "no para abolir a la par los dos extremos, capital y trabajo asalariado, sino para atenuar su antítesis y convertirla en armonía”. ${ }^{4}$ Dado que son existencias parasitarias al interior del Estado capitalista, este se refleja en su pensamiento como un absoluto, o hasta como el absoluto por excelencia. Contraponen a la teoría marxiana una utopía cualquiera que, una vez despojada de sus frases más o menos sonoras, equivale a la glorificación del Estado existente.

La más reciente autoridad de esta noble serie es el filósofo de moda Oswald Spengler, cuyo libro, La decadencia de Occidente-de a momentos ingenioso, pero, en esencia, absolutamente diletante-, obtuvo recientemente el éxito, que en realidad debería haber correspondido al profundo trabajo de Ernst Bloch, Geist der Utopie (Espíritu de la utopía). El nuevo libro de Spengler, Prusianismo y socialismo, busca "liberar de Marx al socialismo alemán" (8). Es que Marx no vio el gran problema histórico y filosófico de la modernidad, que nuestro filósofo resume así: "Hay tres pueblos de occidente que han adoptado el socialismo en el sentido más amplio: los españoles, los ingleses y los prusianos. Partiendo de Florencia y de París se iniciaba el contraste anárquico en otros dos: italianos y franceses" (33). Por lo tanto, Marx no pudo hacer los siguientes descubrimientos fundamentales. Primero, que no hubo lucha de clases en la Revolución Francesa; que no hay una burguesía francesa en absoluto, porque "cada francés verdadero ha sido y es aún hoy día un buen burgués. Cada alemán verdadero es un obrero" (16); que no hay clases reales en Francia. En segundo lugar, que en Inglaterra no hay Estado; que solo Inglaterra conoce un capitalismo propiamente dicho; que, en consecuencia, solo allí se puede encontrar una estratificación de clases. Así, el Marx superficial, que determinó la situación de clase según la posición en el proceso de producción, es profundizado y superado; la estratificación de clases resulta de las circunstancias financieras, es el contraste entre ricos y pobres. Por lo tanto, el pobre Marx, que no vio todo esto, fue incapaz de ver que el socialismo ya hace mucho tiempo se había realizado... en el reino de Prusia. Por eso Marx no pudo comprender el problema del Estado, por eso su "alabanza diletante" (85) a la Comuna de 1871; por eso fue incapaz de apreciar el verdadero sistema de Consejos que el barón vom Stein había planificado hace cien años. De este

3 "Privatdozent", docente universitario que no tiene un vínculo estable con la institución universitaria en la que enseña.

4 Marx, K. (2003). El 18 Brumario de Luis Bonaparte. Madrid: Fundación Federico Engels.

5 Todas las citas pertenecen a Spengler (2014) pero fueron modificadas cuando resultó necesario. 
modo, el socialismo superficial es reemplazado por el filosóficamente profundizado. Este socialismo es un principio de autoridad, "en su sentido técnico, es el principio del funcionario" (85). Así, es natural que, aunque no reconocida por Marx, la socialización ya había sido realizada y fue "desarrollada [...] desde el Gobierno de Federico Guillermo I hasta la época de Bismarck" (98). Pertinente a esta profundidad filosófica, también se revaloriza el concepto de la Internacional: "La verdadera Internacional es imperialismo" (93). Por eso ambos partidos, conservadores y socialistas como representantes del socialismo profundizado -en el que "los conservadores eran mejores oficiales y los socialistas las mejores tropas" (71)- están unidos. La reconciliación entre estos hermanos enemistados es el objetivo del socialismo redescubierto filosóficamente.

¿Vale la pena criticar tales escritos? No son poco interesantes como síntomas. Que la única cita de Spengler provenga de Lensch ${ }^{6}$ demuestra no solo su ilimitada ignorancia en cuestiones de marxismo, pero también nos muestra a dónde necesariamente debían conducir la teoría y la praxis de los socialistas de derecha alemanes. Por lo demás, este librito no se distingue en nada de la "superación" del marxismo, ya conocida de los tiempos de Dühring y compañía, que siempre ha culminado con la glorificación del Estado prusiano. Lo único nuevo es que la revolución no pudo curar a los alemanes del, como dice Engels, "servilismo que ha penetrado en la conciencia nacional" ${ }^{7}$

6 Paul Lensch (1873-1926), político alemán, miembro del Partido Socialdemócrata.

7 Engels, F. Anti-Dühring. La revolución de la ciencia por el señor Eugen Dühring. Madrid: Fundación Federico Engels, 2014, p. 264. 